\section{UK charity launches assault on deadliest cancers}

Cancer Research UK is to fund more work on pancreatic, lung and oesophageal cancer and will open up to 20 more research centres as part of its plans to disburse $£ 1.5$ billion (US $\$ 2.3$ billion) over the next five years. The charity, the world's largest independent

\title{
Europe's synchrotron sharpens up its X-rays
}

The European Synchrotron Radiation Facility (ESRF) has won approval to begin a $€ 177$-million (US\$224-million) upgrade of its facility in Grenoble, France (pictured). On 25 November, the ESRF council, which represents 19 member states, approved funding for construction to begin on eight new beamlines for the facility. The new lines will deliver sharply focused beams of $X$-rays just tens of nanometres in diameter.

Among other applications, researchers plan to use them to image the nanometre-scale features of various materials and follow the progress of chemical reactions. Other synchrotrons have achieved similar-sized beams, but the ESRF's will be the first available for general use by scientists. Construction of all eight lines is expected to run until the end of 2015, but the first ones could be ready as soon as mid-2013.

funder of cancer research, already provides core funding for seven dedicated cancer institutes in Britain.

Compared with other cancers, such as prostate and breast cancer, for which survival rates have improved, "essentially no progress" has been made in preventing deaths from pancreatic, lung and oesophageal cancers, says Harpal Kumar, Cancer Research UK's chief executive.
The charity recently delayed making decisions on applications for project grants, due in January 2009, until April. But it will press ahead with its five-year strategy commitment despite the financial downturn. "We are weathering the storm," says Kumar. For a longer version of this story, see http://tinyurl.com/5lulga

\section{Greenhouse gases hit modern-day highs}

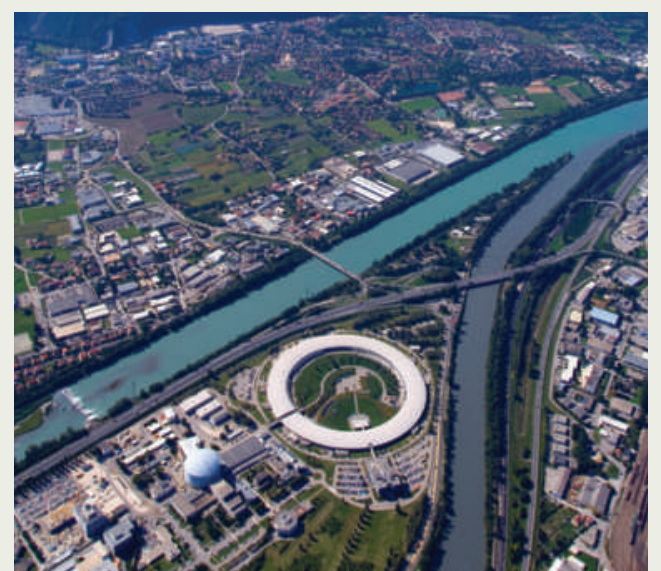

Atmospheric concentrations of greenhouse gases reached new highs in 2007, according to the most recent analysis by the World Meteorological Organization (WMO).

Concentrations of carbon dioxide, methane and nitrous oxide - which together contribute $88 \%$ of the anthropogenic global-warming effect were last year $37 \%, 156 \%$ and $19 \%$ above pre-industrial levels, respectively.

Since 1990, total radiative forcing - the re-radiation of heat back towards Earth's surface - by all long-lived heat-trapping gases has increased by $24 \%$, the WMO reports. In 2007, the average concentration of carbon dioxide rose to 383 parts per million, an increase of $0.5 \%$ from 2006. Methane and nitrous oxide concentrations also rose, reaching new highs of 1,789 


\section{and 321 parts per billion. The increases are in line with the Intergovernmental Panel on Climate Change's predictions for greenhouse-gas concentrations in a world experiencing rapid economic growth. \\ Europe rejects Wisconsin's key stem-cell patent}

Human embryonic stem cells whose derivation requires the destruction of embryos cannot be patented, the appeals board of the European Patent Office (EPO) ruled on 27 November (see also 'Europe to pay royalties for cancer gene', page 556).

The decision concludes a 13-year battle over a patent application from the Wisconsin Alumni Research Foundation for a method to derive stem cells from the undifferentiated cells of human embryos. The patent, which has been granted by the US Patent and Trademark Office, would also have covered some of the most commonly used human embryonic stem-cell lines.

The EPO decided that the patent contravenes a clause in its own convention, which says that anything whose exploitation is considered "contrary to public order or morality" cannot be patented. The ruling will not affect patents or patent applications on adult stem cells.

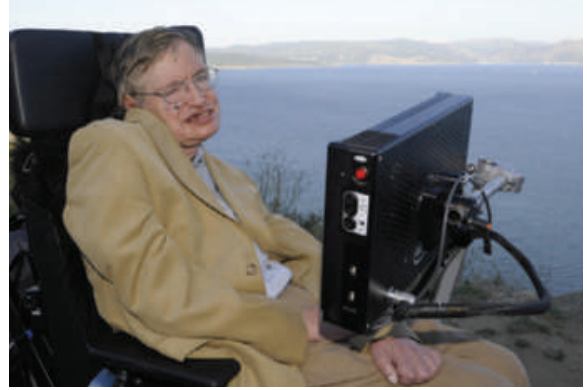

Stephen Hawking is taking a position in Canada.

\section{Hawking plans long commute to Canada}

Theoretical physicist Stephen Hawking, soon to retire as Lucasian professor of mathematics at the University of Cambridge, $\mathrm{UK}$, has accepted a distinguished research chair at Canada's Perimeter Institute for Theoretical Physics in Waterloo, Ontario. The post is a travelling position, which means Hawking can stay on as an emeritus professor at Cambridge while making regular visits to Canada.

The executive director of the institute, Neil Turok, who took up his post in October, is a former Cambridge colleague of Hawking's. Following his retirement from Cambridge at the end of the current academic year, Hawking, who is almost completely paralysed by amyotrophic lateral sclerosis, will begin his visits to the Canadian institute next summer. Applications for the Lucasian chair will close on 15 December.

\section{Chemicals firm cancels plans for biodiesel plant}

The world's third-largest chemicals company, Ineos, has shelved plans to build four large European biodiesel plants because of the "continued and prolonged global economic downturn".

The plants - in Belgium, France, Germany and Britain - were intended to come on stream over the next four years. Together, they would have produced a total of 2 million tonnes of fuel annually.

Ineos is the largest private company in Britain and was founded just over a decade ago. The company's rapid growth has been funded by debt financing, which it used to acquire more than 70 chemical-production sites across 14 countries.

The company says it is now cancelling all non-essential expenditure, and recently announced that it hoped to renegotiate the terms of loans totalling more than $\mathfrak{E 5}$ billion (US\$7.4 billion). 